\title{
Adult Learning, Instruction and Programme Planning: Insights from Freire
}

\author{
P Mayo, University of Malta, Msida, Malta \\ (c) 2010 Elsevier Ltd. All rights reserved.
}

\section{Introduction}

Paulo Freire (1921-97) was one of the most influential educationists of the twentieth century. It is from a Freirean perspective that this article on adult learning, instruction, and program planning is written.

Argentinean scholar Daniel Schugurensky says, with reference to adult education, that: "in Latin America, Paulo Freire constitutes a watershed. There is before and after Freire" (Schugurensky, 1998: 344). Several years earlier, another Argentinean scholar, Carlos Alberto Torres, remarked: "We can stay with Freire or against Freire, but not without Freire" (Torres, 1982: 94). In addition, although Freire was undoubtedly one of the most heralded educators of the twentieth century, who inevitably has his detractors, his influence extends beyond the field of education to be felt in a variety of areas, including sociology, political theory, development studies, theology, philosophy, cultural studies, anthropology, language studies, and communications.

Paulo Freire suffered imprisonment and exile for his efforts in planning what was perceived as being a subversive approach to literacy in Brazil in the early 1960s. Freire subsequently worked, as a person in exile, in Chile, Massachusetts, and Geneva. During his 16-year period of exile, he was frequently called upon by revolutionary governments to assist them in developing and evaluating educational projects. He also engaged in projects with a variety of groups in different parts of the world. After his return to Brazil from exile, which, on his own admission, he had to relearn, he entered the complex domain of municipal educational administration in São Paulo, one of the world's largest cities.

Freire was most prolific as a published writer, with many of his works having been translated into English and other languages. Freire's better-known work, Pedagogy of the Oppressed, is regarded by many to be exemplary in the way it provides reflections on his many worlds of social action in a process that also involves constant recourse to theory, with Freire drawing on many sources in this regard, including Marxism, phenomenology, Christian personalism, liberation theology, and postcolonialism.

\section{Praxis}

\section{Knowledge of the Community}

Freire's pedagogy emerged from the Latin American tradition of popular education which incorporates a strong degree of nonformal education. Nonformal education is not laissez faire pedagogy, but includes a certain degree of planning and organization. In the classic Freirean approach, the entire process of planning involves an intimate knowledge of the community in which the learning is to take place. The team of educators and project organizers, and other project participants, were allowed to mix with community members in a variety of settings, including their most informal settings, listen to their speech patterns and concerns, as well as identify some of the thematic complexes of the community itself. This approach was repeated and reinvented by Freire within the context of public educational administration when he served as educational secretary in the municipal government of São Paulo in his native, Brazil (O'Cadiz et al., 1998).

\section{Codification}

Once the information was gathered, the team worked together and consulted community members, besides other persons connected with the locality, to draw up a plan of action that focused on the reality gleaned from the research carried out in the locality. Important aspects of this reality were thus codified in the form of pictures, subjects for discussion, plays, generative themes, and other pedagogical approaches. The material connected with the participants' framework of relevance, but was codified in such a way that it allowed the participants to gain some critical distance from the matter being discussed. This process of gaining critical distance is referred to as praxis. Praxis is a key concept in the Freirean approach to education.

Praxis has a long history dating back to the time of the ancient Greeks and at least Aristotle. It involves reflection upon action for transformative learning and action. This is how Freire defines praxis in Pedagogy of the Oppressed:

But human activity consists of action and reflection: it is praxis, it is transformation of the world. (Freire, 1970a/ 1993: 125)

\section{Exile as Praxis}

Freire goes on to say that the whole process involved needs to be enlightened through theory. It is praxis that lies at the heart of Paulo Freire's notion of critical literacy. Freire and other intellectuals, with whom he has 
conversed in talking books, conceive of different learning situations in their life as forms of praxis. This applies to adult learning in its broadest contexts including learning from life situations - informal learning. These situations are viewed as moments when people can gain critical distance from the context they know to perceive it in a more critical light. For instance, Freire and the Chilean Antonio Faundez considered exile a form of praxis (Freire and Faundez, 1989). Freire also makes statements to this effect in a book with Betto and Freire (1986). He refers to the period of exile as one that provided a profoundly pedagogical experience, thus echoing Frei Betto, who also presented, in the same discussion, his 4-year experience of imprisonment under the military dictatorship as one that had a strong and important pedagogical dimension. Freire's period of exile is presented as a time during which he gained distance from Brazil and began to understand himself and Brazil better. It was a case of obtaining distance from what he had carried out in Brazil to prepare himself better to continue being active outside his context.

\section{Antithesis of Praxis: Empty Theorizing and Mindless Activism}

Freire relates the whole process of action and reflection to theory and practice (ibid.). Freire's work underscores the point that action on its own, isolated from reflection, constitutes mindless activism. Likewise, reflection on its own, divorced from action, constitutes empty theorizing. It is for this reason that Freire, in keeping with the Marxist tradition, regards one's material surroundings as the basis for the development of one's consciousness. In the words of Marx and Engels, "Consciousness is, therefore, from the beginning a social product, and remains so as long as men (sic.) exist at all" (Marx and Engels, 1970: 51). The notion of praxis that lies at the heart of Freire's pedagogical approach and which informs learning contexts developed on Freirean lines is akin to Marx and Engels' notion of revolutionizing practice as expressed in the Theses on Feuerbach.

\section{Dialectical Relations}

The action-reflection-transformative action process is not sequential, but dialectical (Allman, 1999, 2001). In the introduction to the special issue of Convergence dedicated to Freire, Allman et al. (1998) state:

Dialectical thinkers understand the internal relations among all phenomena. In the case of human beings or groups, this is a social relation which could be harmonious but which, thus far in history, normally has been antagonistic, resulting in various social relations that Freire collectively refers to as the oppressor-oppressed relation (e.g., class relations, gender, race, colonial, etc.) The antagonism is often so great that nothing short of abolishing the dialectical relation will improve the situation. When there are no longer the two opposing groups, the possibility emerges of human beings uniting in love, with a commitment to social justice and to care for all of our social and natural world (Allman et al., 1998: 10).

\section{Teacher Student and Student Teachers}

Learners can be assisted in this process of praxis, of coming to understand their reality in a more critical light, through a process of what Freire calls authentic dialog and participatory learning, as well as collective learning. The educator learns from the learners in the same way that the latter learn from her or him, the roles of educator and learner becoming almost interchangeable. In what has become a classic formulation, Freire wrote about the teacher student and students teachers. The educator is therefore regarded as a person who, while engaging in dialog with the learners, is also being taught by them. The learners, for their part, are also teaching while being taught (Freire, 1970a/1993: 80). In a dialog with Ira Shor, Freire states that:

\begin{abstract}
Liberatory education is fundamentally a situation where the teacher and the students both have to be learners, both have to be cognitive subjects, in spite of their being different. This for me is the first test of liberating education, for teachers and students both to be critical agents in the act of knowing. (Shor and Freire, 1987: 33)
\end{abstract}

\section{Learner as Subject}

The educator would therefore transcend the boundaries of his/her social location to understand and act in solidarity with the learners, no longer perceived as other. In adopting a Freirean approach, one would regard educators and learners as subjects in a humanizing relationship. Solidarity is the hallmark of this pedagogical relationship. The learner's reality constitutes an integral part of the subject matter that, therefore, becomes a mediator between the two subjects in question, that is, the educator and learner. Freire goes on to state that the dialogical process of education marks "the sealing together of the teacher and the students in the joint act of knowing and re-knowing the object" (Shor and Freire, 1987: 100). Borrowing from this conversation between Freire and Shor, one can argue that anything that the educator already knows is relearned when studied again with the learners, a point confirmed by Freire in the same conversation (ibid.).

\section{Learners and Educators Not Equal}

However, and here comes the apparent contradiction, a Freirean approach to learning based on dialog is one wherein educators and learners are not on an equal footing. 
Obviously, we also have to underscore that while we recognize that we have to learn from our students ... this does not mean that teachers and students are the same...there is a difference between the educator and the student. (Freire, 1985: 177)

Much depends on the specific situation in which the adult learning process occurs; however, it would be amiss to celebrate learner voices uncritically since they are never innocent (Aronowitz and Giroux, 1991: 130-131). They contain various manifestations of the oppressor consciousness which ought to be challenged. Dialog, as conceived by Freire, also involves educators allowing themselves to be challenged and to constantly undergo self-reflection and scrutiny to confront the oppressor consciousness within. In short, both educator and learner need to address their contradictions in an ongoing process of gaining greater coherence. The educator needs to help create the conditions whereby the learners develop the confidence necessary to challenge him or her where necessary in a situation of mutual respect and trust. This is part of the humility which, according to Freire, all critical educators must show.

\section{Directive Approach}

The directive nature of the educational process is affirmed (see, e.g., the discussion with Moacir Gadotti and Sergio Guimarães published in Brazil in 1989 Gadotti et al., 1995: 50). Guarding against the perceived danger of a laissez faire pedagogy, resulting from a misconception of his particular notion of dialog, Freire emphasizes this directivity in the conversation with Ira Shor and elsewhere: "At the moment the teacher begins the dialogue, he or she knows a great deal, first in terms of knowledge and second in terms of the horizon that he or she wants to get to. The starting point is what the teacher knows about the object and where the teacher wants to go with it" (Shor and Freire, 1987: 103).

Freire makes it clear that he believes that the educators' pedagogical action is guided by a particular political vision and theoretical understanding. Freire, after all, considers education to be a political act, there being no such thing as a neutral education, with educators having to answer the question "for whom and on whose behalf they are working" (Freire, 1985: 180). Freire once stated that the learning experience entails a process of research and curiosity with all the elements involved - teacher, student, knowing object, methods, and techniques - providing direction (Fabbri and Gomes, 1995: 96). He argues that it is for this reason that every form of educational practice is directive, but not necessarily manipulative, and that every educational practice cannot be neutral; a directive practice cannot be neutral - no one is neutral when facing an objective to be reached (Fabbri and Gomes, 1995).

\section{Authority and Authoritarianism}

Educators therefore have a directive role; they need to exercise their authority, an authority derived from their competence as pedagogs. Freire, however, draws an important distinction between authority and authoritarianism. It is imperative that the authority derived from one's pedagogical competence does not degenerate into authoritarianism: "...the democratic teacher never, never transforms authority into authoritarianism" (Shor and Freire, 1987: 91; on this, also see Horton and Freire, 1990: 181). This authoritarianism would render the difference that exists between educator and learner antagonistic (Gadotti et al., 1995: 50). The educator exercises what Ira Shor calls democratic authority (Shor, 1992: 156-158).

What we have, therefore, in Freire's nuanced concept of dialog is a paradox rather than a contradiction. Freire provides a complex notion of learning and instruction, based on dialog. Freire (1974) feels that the traditional educator regards the knowledge he or she possesses, often captured in the lesson plan, as complete. The Freireaninspired educator regards knowledge as dynamic, an object of co-investigation and unveiling that necessitates the participation of co-knowing subjects - the learners. The process of knowing involved, with respect to the object of knowledge, is considered by both educator and learner as incomplete (see Allman, 2001).

\section{Tact and Prudence}

Freire has even advocated tact and prudence when engaging in a dialogical approach, conceding that people who have been conditioned by many years of exposure to banking education do not immediately do away with this conditioning to embrace dialog. They often resist attempts at dialog, perhaps even misconstruing a dialogical approach for lack of competence on the educator's part. Freire concedes that some instruction is necessary at times. It is for this reason that he once stated that an educator can alternate between traditional and progressive teaching. It is as though he seems to be saying that, in such difficult circumstances, dialog should be introduced only gradually (see Horton and Freire, 1990: 160). Elements of the old pedagogy can coexist with the new in an overall context that, however, privileges democratic relations.

Given the strong relationship between knowledge and the learner's existential situation in Freire's approach, one assumes that the participant has a repository to draw on. This repository consists of one's life experience. The participant is therefore encouraged to draw on this experience in order to arrive at new knowledge and at a new awareness. In drawing on this experience, one is able to relate to the codified material. The educator enables this process to occur not by depositing knowledge, but by 
engaging the learner's critical faculties. Rather than being a dispenser of knowledge, the educator poses questions and problematizes issues. In this problem-posing education, the pedagogy applied is primarily not that of the answer, but that of the question (Bruss and Macedo, 1985).

\section{Collective Dimensions of Learning}

In adopting a democratic, dialogical approach, the circle or learning setting serves as a microcosm, indicating the potential that can exist within contexts characterized by democratic social relations. Furthermore, knowledge itself is democratized and is therefore not presented any longer as the preserve of a privileged minority. In addition, the knowledge disseminated is in itself democratic in that its starting point is the life experienced by the participants and it serves their interest. Finally, it is group knowledge that emerges from this experience that emphasizes the collective dimensions of learning and of action for social change. Freire argued that one engages in the task of becoming more fully human not on one's own (it is not an individualistic endeavor), but in solidarity with others (Freire, 1970a/1993: 85-86). This having been said, one eventually moves beyond the here and now to gain a greater level of awareness. "Educands' concrete localization is the point of departure for the knowledge they create of the world" (Freire, 1994: 85). It is just the point of departure; for the here and now represents only the starting point of an ongoing adult learning process and not the endpoint. Remaining within the here and now constitutes, according to Freire, a case of populism or basismo. In remaining there and not moving beyond (through co-investigation of the object of inquiry), one would be engaging in basism, the romanticization (or mythification) of the vernacular (see Freire, 1994: 84).

It is this aspect of a Freire-inspired theory of instruction, learning, and curriculum planning that renders it quite different from the more liberal notion of learning through dialog which, often, erroneously passes off as Freirean.

The insights we derive from Freire, with regard to program planning, learning, and instruction in adult education, are described in the following section.

\section{Planning Together}

One should not enter the community and impose a program on its members, but should, on the contrary, engage with a team of researchers, preferably including people with different disciplinary backgrounds and certainly including both educators and potential project participants (the adult learners), in studying the community, where the learning setting is to be developed, at close hand. This process of study or research comprises informal meetings with community members. The planning of materials occurs on the basis of the insights and information gleaned from the research.

\section{Learning and Instruction}

\section{Learning Based on Action and Reflection}

The approach throughout is one based on praxis involving critical reflection on the area of action, which also involves recourse to theory, but which entails an authentic notion of dialog in which the subject of enquiry is the focus of collective co-investigation. The research leads to insights which are to form the basis of the codified learning material whereby the educator enables the learners to gain critical distance from the community they know to be able to perceive it in a different, hopefully more critical, light. The same applies to the adult educator herself or himself who also gains critical distance from the object of co-investigation and can come to perceive it in a more critical light. We have seen how even exile is viewed by Freire and co-authors, engaged in dialog with him, as a form of praxis, of gaining critical distance.

Adult educators working with migrants in this evergrowing context for adult education can take a leaf out of Freire's book. One of the challenges for critical pedagogical work with migrants, to emerge from this Freirean insight, is that of enabling the migrants to read not only the world they now inhabit as immigrants, but also the world they left through a process of obtaining critical distance from their context of origin. This can hopefully lead to a greater understanding of the politics of their own dislocation.

\section{Dynamic Knowledge}

Through this process of praxis, based on reflection on action, knowledge is conceived as dynamic rather than static. The approach to learning is directive since learning is conceived as a political act. The roles of adult educator and adult learner are almost interchangeable, as all learn from each other, but this is not to say that the adult learner and adult educator are on an equal footing. The latter must have a certain amount of authority which should not be allowed to degenerate into authoritarianism lest the spirit of genuine dialog be destroyed.

\section{Starting with the Learners' Existential Realities}

Only through dialog does the group collectively learn to unveil the contradictions that underlie the reality on which it is focusing. Adult educators are encouraged to show tact when promoting dialogical relations and there are moments when they temper dialog with a certain degree of instruction, especially on consideration that people exposed to 
banking education for years do not embrace dialog easily. The starting point of co-investigation is the learner's existential reality which is, however, not the be all and end all of the learning process, lest one be guilty of populism or basismo. Adult educators must demonstrate the humility necessary to be disposed to relearn that which they think they already know through their dialogic interactions with the rest of the learning group or community.

\section{Bibliography}

Allman, P. (1999). Revolutionary Social Transformation: Democratic Hopes, Political Possibilities and Critical Education. Westport, CT: Bergin and Garvey.

Allman, P. (2001). Critical Education against Global Capitalism. Karl Marx and Revolutionary Critical Education. Westport, CT: Bergin and Garvey.

Allman, P., Mayo, P., Cavanagh, C., Lean Heng, C., and Haddad, S. (1998). Introduction. " . . .the creation of a world in which it will be easier to love" Convergence XX1(1 and 2), 9-16.

Aronowitz, S. and Giroux, H. (1991). Postmodern Education. Minneapolis, MN: University of Minnesota Press.

Betto, F. and Freire, P. (1986). Una Scuola Chiamata Vita. Bologna: E.M.I.

Bruss, N. and Macedo, D. (1985). Toward a pedagogy of the question: Conversations with Paulo Freire. Journal of Education 167, 7-21.

Fabbri, F. and Gomes, A. M. (1995). La mia pedagogia: Paulo Freire risponde a professori e studenti bolognesi. In Gadotti, M., Freire, P., Guimarães, S., Bellanova, B., and Telleri, F. (eds.) Pedagogia: dialogo e conflitto, pp 92-103. Torino: Società Editrice Internazionale.

Freire, P. (1970a/1993). Pedagogy of the Oppressed, 30th anniversary edn. New York: Continuum.

Freire, P. (1974). Authority versus Authoritarianism. Audiotape, in Series: Thinking with Paulo Freire. Sydney, NSW: Australian Council of Churches.

Freire, P. (1985). The Politics of Education. South Hadley, MA: Bergin and Garvey.

Freire, P. (1994). Pedagogy of Hope. New York: Continuum.

Freire, P. and Faundez, A. (1989). Learning to Question. A Pedagogy of Liberation. Geneva: World Council of Churches.

Gadotti, M., Freire, P., and Guimarães, S. (1995). Pedagogia: dialogo e conflitto. (Bellanova, B. and Telleri, F. (eds.)). Torino: Società Editrice Internazionale.

Horton, M. and Freire, P. (1990). We Make the Road by Walking. Conversations on Education and Social Change. Philadelphia, PA: Temple University Press.

Marx, K. and Engels, F. (1970). The German Ideology. Arthur, C. J. (ed.) London: Lawrence and Wishart.

O'Cadiz, P., Wong, P. L., and Torres, C. A. (1997). Education and Democracy. Paulo Freire, Social Movements and Educational Reform in São Paulo. Boulder, CO: Westview Press.
Schugurensky, D. (1996). Paulo Freire: From pedagogy of the oppressed to pedagogy of hope. In Reno, H. and Witte, M. (eds.) 37th Annual AERC Proceedings. Tampa: University of Florida.

Shor, I. (1992). Empowering Education. Critical Teaching for Social Change. Chicago, IL: The University of Chicago Press.

Shor, I. and Freire, P. (1987). Pedagogy for Liberation Dialogues on Transforming Education. South Hadley, MA: Bergin and Garvey.

Torres, C. A. (1982). From the pedagogy of the oppressed to a Luta Continua - the political pedagogy of Paulo Freire. Education with Production 2, 76-97.

\section{Further Reading}

Darder, A. (2002). Reinventing Paulo Freire. A Pedagogy of Love. Boulder, CO: Westview Press.

Gadotti, M. (1994). Reading Paulo Freire. His Life and Work. Albany, NY: SUNY Press.

Gadotti, M. (1996). Pedagogy of Praxis. A Dialectical Philosophy of Education. Albany, NY: SUNY Press.

Kidd, R. and Kumar, K. (1981). Co-opting Freire: A critical analysis of pseudo-Freirean adult education. Economic and Political Weekly XVI (1-2), 27-36.

Kirkwood, G. and Kirkwood, C. (1989). Living Adult Education: Freire in Scotland. Milton Keynes, UK: Open University Press.

Marx, K. and Engels, F. (1978). The Marx-Engels Reader. (Tucker, R. (ed.)). New York: W.W. Norton.

Mayo, P. (2004). Liberating Praxis. Paulo Freire's Legacy for Radical Education and Politics. Westport, CT: Praeger.

Roberts, P. (2000). Education, Literacy, and Humanization Exploring the Work of Paulo Freire. Westport, CT: Bergin and Garvey.

Saul, A. M. (1995). Municipal educational policy in the city of São Paulo, Brazil (1988-1991). In Torres, C. A. (ed.) Education and Social Change in Latin America, pp 155-162. Melbourne, VIC: James Nicholas Publishers.

Shor, I. (1999). What is critical literacy? Journal for Pedagogy, Pluralism and Practice 4(1). http://www.lesley.edu/journals/jppp/intro.html (accessed May 2009).

Steiner, S., Krank, M., McLaren, P., and Bahruth, R. (eds.) (2000). Freirean Pedagogy, Praxis, and Possibilities. Projects for the New Millennium. New York: Falmer.

Stromquist, N. (1997). Literacy for Citizenship; Gender and Grassroots Dynamics in Brazil. Albany, NY: SUNY Press.

Taylor, P. V. (1993). The Texts of Paulo Freire. Buckingham, UK: Open University Press.

Telleri, F. (ed.) (2002). /l Metodo Paulo Freire. Nuove technologie e sviluppo sostenibile. Bologna: CLUEB.

Torres, C. A. (1993). From the pedagogy of the oppressed to a Luta Continua - the political pedagogy of Paulo Freire. In McLaren, P. and Leonard, P. (eds.) Paulo Freire: A Critical Encounter, pp 119-145. London: Routledge.

Torres, C. A. (1994). Paulo Freire as secretary of education in the municipality of São Paulo. Comparative Education Review 38, 181-214. 